\title{
Vestígios de um Princípio Protestante: Uma leitura da educação superior na Assembleia de Deus no Brasil a partir de elementos da teoria da religião de Paul Tillich
}

\author{
Marcelo Lopes*
}

\section{RESUMO}

O presente ensaio tem por objetivo propor uma interpretação do fenômeno da educação superior na Assembleia de Deus no Brasil, fenômeno que denominamos "primavera educacional", que ocorre hodiernamente nessa denominação e cujo paradigma é a Faculdade Evangélica de Tecnologia, Ciências e Biotecnologia. Para tanto, nos valemos de dois elementos da teologia de Paul Tillich, quais sejam, o Princípio Protestante e o Ultimate Concern. O texto está estruturado em dois tópicos. O primeiro ocupa-se de problematizar o Princípio Protestante no âmbito da Assembleia de Deus, mormente quanto à educação superior. O segundo aborda a experiência pentecostal assembleiana a partir do conceito de preocupação suprema, cujo foco recai, também, na educação superior. Trata-se, portanto, de uma abordagem teológica baseada em elementos teológicos tillichianos.

Palavras-chave: Pentecostalismo; Assembleia de Deus; Educação Superior; Princípio Protestante; Ultimate Concern.

* Doutorando e mestre em Ciência da Religião pela Universidade Federal de Juiz de Fora, especialista em Ciências da Religião pela Faculdade de São Bento do Rio de Janeiro e bacharel em Teologia pela Faculdade Evangélica de Tecnologia, Ciências e Biotecnologia. Integrante do Grupo de Pesquisa - NEPROTES (Núcleo de Estudos em Protestantismo e Teologias - UFJF/CNPq). Bolsista do PPCIR-UFJF. E-mail para contato: montanhista-ms@hotmail.com. Endereço do currículo Lattes: <http://buscatextual.cnpq.br/buscatextual/visualizacv.do?id=K4444997P3>. 


\title{
VESTIGES OF A PROTESTANT PRINCIPLE: A READING OF HIGHER EDUCATION IN THE ASSEMBLY OF GOD IN BRAZIL FROM PAUL TILLICH'S THEORY OF RELIGION ELEMENTS
}

\begin{abstract}
The purpose of this text may be more pretentious in the title than the content itself. This is an effort to contribute to an understanding of the phenomenon of higher education in the Assembly of God in Brazil. For this, we followed the theory of Paul Tillich's religion as a hermeneutic key to approach the object. We emphasize, however, that this does not imply any kind of panacea or peremptory answer to the questions the phenomenon entails. Before, we think that this reading, among many others, can be enriching in that it offers an alternative to those approaches that treat the object as derivation or social function only. Here, therefore, we are interested much more its dialectic with culture starting from Tillich. Keywords: Pentecostalism; Assembly of God; higher education; protestant principle.
\end{abstract}

\section{Considerações iniciais}

O pentecostalismo vem sendo objeto de escrutínio científico já há algum tempo no Brasil, sobretudo a partir da segunda metade do século $\mathrm{XX}$, de forma mais progressiva. Nesses estudos, no entanto, preponderaram até bem recentemente as abordagens das Ciências Sociais. Embora se reconheça suas contribuições valiosas, e que não foram poucas, o fenômeno religioso em si e o pentecostal, em particular, foram tomados predominantemente como derivados de alguma estrutura ou no desempenho de alguma função social, mas quase nunca lhes foi outorgada a autonomia devida, enquanto objeto de pesquisa científica e manifestação religiosa legítima ${ }^{1}$, no caso do pentecostalismo.

\footnotetext{
Não estamos aqui fazendo qualquer apologia ao pentecostalismo. No entanto, vale a pena ressaltar que se pode perceber, sem muito esforço, em diversos textos acadêmicos certa "má vontade" com relação a esse tipo de religiosidade. Não faltam abordagens que o retratam como deturpação do verdadeiro cristianismo, associação à ignorância e ao misticismo. Tais perspectivas são provenientes, quase em sua totalidade, de estudiosos cuja confissão ou pertença religiosa se situa no gradiente do protestantismo histórico. Por outro lado, há também uma generalização por parte de uma parcela de cientistas sociais com relação a episódios de agressões, por pentecostais, a templos ou praticantes das religiões de matriz afro-brasileiras. Nesse caso, ou os pesquisadores são nativos ou nutrem uma simpatia, afinidade, enfim, uma "boa vontade" para com tal religiosidade. Mas o inverso não é verdadeiro. Com isso não estamos eximindo o pentecostalismo de quaisquer excessos, mas talvez seja interessante ler tais textos sob a suspeição de uma epoché parcial, ao menos.
} 
Tal situação foi um dos motivos que deu ensejo à pertinente critica de Paul Freston sobre as abordagens acerca desse fenômeno religioso: "a história do pentecostalismo brasileiro não tem recebido praticamente nenhuma atenção acadêmica (...) a sociologia do pentecostalismo tem inovado apenas no nível micro; há pouco estudo sobre a evolução das igrejas e seu relacionamento com a sociedade" (apud SIEPIERSKI, 1997, p. 49). Essa crítica, embora pertinente à época, já se mostra relativamente defasada. Com isso não estamos afirmando que as abordagens funcionalistas do pentecostalismo já foram ultrapassadas, mas percebe-se esforços cada vez mais crescentes no sentido de se pesquisar o pentecostalismo com a propriedade que lhe é devida, isto é, como fenômeno religioso per se, e não como uma derivação ou função social apenas.

Pensamos que esta mudança tem uma contribuição significativa que advém dos próprios pentecostais, qual seja, a recente entrada de adeptos da fé pentecostal na academia. Este cenário outrora pouco provável já se constitui, atualmente, uma realidade pujante. Uma demonstração evidente desse renovo é que nas Faculdades EST, por exemplo, o Programa de Pós-graduação em Teologia abriu edital para inscrições para a seleção de discentes pentecostais do doutorado à bolsa de estudo da EMW - Evangelisches Missionswerk da Alemanha ${ }^{2}$.

Sublinhe-se, contudo, que o exemplo supracitado não se constitui uma exceção, antes, sem muitas dificuldades, pode-se verificar nos programas de pós-graduação em Teologia e, mormente, em Ciências da Religião da Universidade Metodista de São Paulo - UMESP, Universidade Presbiteriana Mackenzie - UPM, Pontifícia Universidade de São Paulo - PUC-SP, e, Universidade Federal de Juiz de Fora - UFJF, por exemplo, um número significativo de discentes oriundos do pentecostalismo clássico, cuja pertença é predominantemente de fiéis da Assembleia de Deus no Brasil (AD).

Entrementes, há outros exemplos de inserção pentecostal na academia que podem ser aqui destacados. Duas iniciativas são endógenas ao subcampo religioso pentecostal e mais especificamente assembleiano e também corroboram nossa hipótese. A primeira delas é a existência

Informação disponível em: <http://www.est.edu.br/downloads/pdfs/Edital_n_05_Bolsas_EMW_DO.pdf $>$. Acesso em: 13 set. 2013. 
da Rede Latino-americana de Estudos pentecostais (RELEP) ${ }^{3}$, fundada em 1998 e que congrega estudiosos do fenômeno pentecostal, sejam eles nativos ou não; a segunda, e mais específica, é a Rede de Estudos Assembleianos (REA) ${ }^{4}$, criada em 2015 e composta por pesquisadores interessados no nicho assembleiano. Esta última comporta muitos pesquisadores assembleianos obviamente, mas não só, uma vez que é aberta também para quaisquer pesquisadores interessados no assembleianismo, sejam eles nativos ou não.

Assim, nosso texto busca interpretar justamente este fenômeno novo, e, como afirmamos, não pretendemos reduzir nosso objeto de pesquisa a qualquer derivação ou função social apenas. Nesse fito, nos valeremos de alguns elementos da teologia de Paul Tillich. É bem sabido que a produção teológico-filosófica tillichiana possui uma densidade granítica, de modo que não seria possível aqui nos valermos de sua totalidade. Contudo, ao menos dois elementos de sua teologia parecem ter um elevado potencial heurístico para o nosso esforço intelectivo empreendido aqui, quais sejam: o princípio protestante e o ultimate concern.

Pensamos, portanto, que esses elementos da teologia de Paul Tillich podem contribuir significativamente para que se possa proceder a uma tentativa de interpretar o fenômeno a partir de um referencial teórico que reconheça sua autonomia e, simultaneamente, dê conta de analisar sua relação com a cultura, pois segundo o próprio Tillich, "a religião não é mera função especial de nossa vida, mas a dimensão da profundidade presente em todas as funções" (2009, p. 42).

\section{Que há de protestante no pentecostalismo?}

Esta pergunta pode parecer inicialmente tácita ou pior, sem sentido algum. Mas sob quais perspectivas se poderia responder a tal questionamento? A sociológica, a antropológica, a histórica, talvez. Mas e do ponto de vista religioso, que resposta poderia ser dada a este questionamento? Partir de suas diferenças teológico-doutrinárias certamente

\footnotetext{
3 Informação disponível em: < http://relepnucleobrasil.blogspot.com.br/p/quem-somos. html>. Acesso em: 13 set. 2016.

4 Informação disponível em: <http://relepnucleobrasil.blogspot.com.br/p/rea-rede-de-estudos-assembleianos.html>. Acesso em: 13 set. 2016.
} 
não contribuiria muito para aclarar o entendimento do fenômeno, tanto mais ao se pensar que o pentecostalismo é uma vertente do gradiente protestante cuja ênfase litúrgica e doutrinária recai sobre a experiência extática sob a égide do Espírito Santo, sobretudo a glossolal. Basta nos ocuparmos um pouco mais detidamente sobre as possíveis respostas, portanto, para que se perceba que, na verdade, emitir tal assertiva não é tão simples assim como possa parecer.

O teólogo e historiador Paulo Donizéti Siepierski, por exemplo, entende, com base na análise de Christian Lalive D’Epiney, que

o pentecostalismo sintetiza o protestantismo (cristocentricidade, biblicismo, união da fé com a ética) com uma forma de espiritualidade que é característica das religiões 'populares' (emoção, ritos de possessão, participação coletiva). Essa síntese, obviamente, não é equilibrada nem homogênea, podendo haver ênfase maior em um ou mais desses fatores em detrimento do restante. Na realidade, isso ocorreu com tal magnitude nas últimas décadas que a própria síntese pode ser questionada (1997, p. 49).

Ora, de fato, ao observarmos os elementos levados em consideração na citação acima, ou seja, cristocentricidade, biblicismo e a união da fé com a ética, não há dúvida de que são comuns tanto ao protestantismo quanto ao pentecostalismo. Mas, por outro lado, também não há emoção no pietismo? Possessão também não caracterizou o quakerismo? Ou ainda, de algum modo, o congregacionalismo não enseja certa participação coletiva? Logo, sob este auspício, se poderia considerar que o pentecostalismo não passa de um protestantismo carismatizado. Bem, não é este o caso. Sabemos que aquilo que Siepierski quis iluminar é uma síntese concomitantemente propositiva e provisória, e inferir a partir desse silogismo que o pentecostalismo é um protestantismo carismatizado, nada mais é do que um sofisma redutor e empobrecedor dessa forma de religiosidade.

Outra resposta possível a tal questionamento foi dada por Luana Cristina Baracho de Moura em relação à AD especificamente, mas que também vale para o pentecostalismo clássico e para o deuteropentecostalismo: 
AD representa o grupo religioso que se caracteriza como protestante e pentecostal e tem sua doutrina baseada em um livro sagrado, a Bíblia, considerando-a como a Palavra de Deus. Denomina-se protestante por seguir os princípios difundidos pela Reforma Protestante, provocada pelas ideias de Martinho Lutero; e pentecostal por defender a atualidade do batismo com o Espírito Santo, os dons de cura e a glossolalia, enunciados proféticos em línguas desconhecidas (2014, p.137).

Conquanto sua resposta tenha coerência e seja sintética, ainda assim a questão persiste: que há de protestante no pentecostalismo? Logo, o que buscamos identificar é uma "essência” que nos autorizaria afirmar, com certo grau de certeza, o que há de protestante no pentecostalismo, além, é claro, desses elementos que D`Epiney propôs e outros tantos que podem ser aventados.

É justamente aqui que a teologia de Paul Tillich pode contribuir para uma interpretação devida do objeto em tela. O próprio título que demos ao presente ensaio já enseja uma contribuição deveras significativa, senão a principal, qual seja, a do Princípio Protestante. A escolha desse conceito não foi eventual, na verdade, foi o conceito que se impôs na resposta ao questionamento inicial desta seção. Isso porque, segundo o próprio Tillich, este princípio protestante "é a possibilidade que faz com que o protestantismo seja "protestante"" (1992, p. 182). Desta forma, tentaremos identificar os indícios ou vestígios de um princípio protestante no pentecostalismo da $\mathrm{AD}$, mormente em sua relação com a educação superior.

Antes, porém, é preciso aclarar um pouco mais esse conceito. Nesse sentido, para Tillich,

o protestantismo tem um princípio situado além de suas realizações. É a força crítica e dinâmica presente em todos os feitos protestantes, sem se identificar com nenhum deles. Não se encerra numa definição. (...) Esse nome, "princípio protestante", vem do protesto dos "protestantes" contra as decisões da maioria católica. Contém o protesto divino e humano contra qualquer reivindicação absoluta feita por realidades relativas, incluindo mesmo qualquer igreja protestante. O princípio protestante é o juiz de qualquer realidade religiosa e cultural, incluindo a religião e a cultura que se chamem "protestantes" (1992, p. 183). 
Diante dessa portentosa proposta tillichiana e cientes da história da $\mathrm{AD}$, não há como deixar de questionar: seria possível haver um princípio protestante na Assembleia de Deus no Brasil? Este questionamento deriva, sobretudo, do conhecimento histórico da intrínseca relação entre a forma de governo episcopal e o ethos assembleiano.

Gedeon Alencar afirma que

não há uma hierarquia única no universo assembleiano, mas um título absolutamente universal em todos os grupos: o pastor-presidente. Essa titulação surge pela primeira vez em 1958, se referindo a Paulo Leivas Macalão, na época dirigente supremo do Ministério de Madureira. (...) À primeira vista, um Paulo Macalão, Cícero Canuto, José Pimentel, e tantos outros, pastores-presidentes, soberanos e vitalícios, sem nenhum órgão que delimitasse suas funções, poderes e autoridade, sem nenhuma mediação de Regimento Interno ou Estatuto para lhes questionar ou limitar suas idiossincrasias; com plena autoridade sobre todos e tudo, sem a necessidade de pedir ou precisar de autorização para mudar pastor local, indicar nomes para consagração, administrar os bens e finanças da igreja, decidir seu próprio salário, de amigos e de familiares, alterar programas e eventos, etc., seriam, assim, despudoradamente déspotas (2012, p. 143-144, grifos do autor).

Esse quadro (quase gótico) "pintado" por Alencar denota bastante da realidade assembleiana, o que agrava ainda mais o nosso questionamento sobre a possibilidade da existência do princípio protestante na $\mathrm{AD}$, quiçá da pregnância de sua radical crítica profética. Todavia, e, ironicamente, foi com o próprio Paulo Leivas Macalão que teve início a celeuma sobre educação teológica regular na $\mathrm{AD}$ que culminou, no tempo presente, na criação da Faculdade Evangélica de Tecnologia, Ciências e Biotecnologia (FAECAD) em agosto de 2005, a Faculdade da Assembleia de Deus ${ }^{5}$ com projeto, inclusive, de se tornar uma universidade; e na hodierna valorização do ensino superior na $\mathrm{AD}$, o que denominamos "primavera educacional" assembleiana.

Segundo as crônicas da própria instituição,

Referimo-nos à AD da Convenção Geral das Assembleias de Deus no Brasil - CGADB. Cumpre destacar isso, pois existem ao menos outras duas convenções, quais sejam, a Convenção Nacional das Assembleias de Deus no Brasil Ministério de Madureira - CONAMAD, e a Assembleia de Deus Vitória em Cristo - ADVEC. 
foi no final da tarde do dia 19 que começaram os primeiros debates convencionas sobre o ensino teológico formal nas Assembleias de Deus. Esses debates se estenderiam até a tarde do dia 20. Anos depois, a Convenção Geral discutiria novamente o assunto em outra serie de debates. Foi o pastor John Peter Kolenda que apresentou o assunto naquela tarde. A pergunta levantada por ele como gancho para entrar no tema foi: "que mais poderemos fazer para contribuir para a idoneidade dos nossos obreiros?" O pastor Paulo Leivas Macalão foi o primeiro a sugerir medidas. A proposta era interessante. Ele falou da possibilidade de as Assembleias de Deus criarem uma escola bíblica noturna para obreiros, com ministrações semanais fixas nos dias em que os obreiros tivessem as noites desimpedidas de cultos principais. Foi apresentado também um plano de estudo por correspondência. Aproveitando o assunto, o missionário norte-americano Lawrence Olson, que chegara ao Brasil havia cinco anos e estava servindo ao Senhor em Lavras (MG), foi mais além, lançado a proposta de as Assembleias de Deus no Brasil abrirem institutos bíblicos, escolas teológicas, seminários pelo país. Como introdução para o seu assunto, o pastor Olson começou citando 1 Timóteo 4.13 para em seguida mostrar "a necessidade de os obreiros se aprofundarem mais na Palavra de Deus e estudarem mais". Após a exposição do missionário, o pastor Paulo Leivas Macalão pediu a palavra para discordar, dizendo que seria "perigoso" investir muito na educação teológica do obreiro. Ele falou "do perigo da muita sabedoria", referindo-se ao intelectualismo, à possibilidade do muito estudo esfriar o obreiro (DANIEL, 2004, p 194, grifo nosso).

É preciso informar ao leitor que um anti-intelectualismo permeou o ethos assembleiano até bem recentemente, e, na verdade, ainda há muitos nichos de resistência à primavera educacional que ora ocorre na AD.

Desta feita, não foi sem motivo que essa celeuma sobre educação teológica regular durou algumas décadas, sempre com forte resistência por parte da liderança nacional e sueca, de modo que não seria possível aqui fazer um apanhado histórico sobre isso, sem digredir totalmente do assunto. Mas o fato é que a FAECAD é um marco de uma primavera educacional que ocorre hodiernamente na AD. Seria possível então afirmar que triunfou o princípio protestante nessa questão?

Não é tão simples assim, obviamente, aquiescer tal questionamento. Mas em fina sintonia com o título que demos ao ensaio, pensamos que se pode falar ao menos em "vestígios" de um princípio protestante. Afirmamos isso baseados no próprio Tillich, pois, segundo ele, o princípio protestante 
não se esgota em nenhuma relação histórica; não se identifica com a estrutura da Reforma, nem do cristianismo primitivo, nem mesmo com formas religiosas. Transcende-as como transcende qualquer forma cultural. Por outro lado, pode aparecer em qualquer uma delas. Trata-se de um poder vivo, dinâmico e atuante (1992, p. 183, grifo nosso).

Talvez seja prematuro afirmar que o princípio protestante tenha triunfado nessa questão específica na $\mathrm{AD}$, mas certamente há evidências suficientes que atestam à existência de vestígios desse princípio protestante. Basta nos lembrarmos de que este princípio

guarda-nos contra as tentativas do finito e do condicional de usurpar o lugar o lugar do incondicional no pensamento e na ação. É o julgamento profético contra o orgulho religioso, a arrogância eclesiástica, e a auto-suficiência secularizada com suas conseqüências destruidoras (TILLICH, 1992, p. 183).

Orgulho religioso, arrogância eclesiástica e auto-suficiência (não secularizada, obviamente), parecem ser atributos inerentes à liderança assembleiana que Gedeon Alencar descreveu logo acima. Interessa-nos saber, porém, de onde provêm os vestígios do princípio protestante que proporcionou que alguns pentecostais ousassem protestar contra esse anti-intelectualismo arbitrário.

Não seria uma antífrase histórica que esse princípio protestante tenha advindo com os missionários estadunidenses a partir de 1936 e não com os missionários escandinavos? Este questionamento procede de uma inferência natural, pois talvez fosse mais provável que esse princípio protestante adviesse da Suécia do que dos Estados Unidos. Ambos os países protestantes, mas o primeiro da primeira geração da Reforma, o segundo de uma terceira geração da Reforma, isto é, dos puritanos do Mayflower. Obviamente não estamos dizendo, com isso, que o protestantismo estadunidense foi degenerado ou se afastou dos princípios da Reforma. Antes, nos referimos a uma situação ideal típica na qual o pentecostalismo escandinavo estivesse mais próximo, historicamente, do princípio protestante do que o pentecostalismo estadunidense ${ }^{6}$.

6 Não é possível dentro dos limites deste texto aprofundar essa temática, portanto, recomendamos ao leitor a obra de Helmut Richard Niebuhr: As origens sociais das denominações cristãs. Acerca do que afirmamos nesse parágrafo, Antonio Gouvêa Mendonça e Prócoro 
Mas como acertadamente afirmou Tillich, que o princípio protestante transcende as formas religiosas culturais e confessionais, bem como pode aparecer em qualquer uma delas; ora, porque não com os missionários pentecostais estadunidenses? De fato foi o que ocorreu, pois o ethos sueco-nordestino possuía esse viés anti-intelectualista, mas pelo que se pode inferir através da história da $\mathrm{AD}$, foi com os missionários estadunidenses que os vestígios do princípio protestante se manifestaram no pentecostalismo assembleiano.

Podemos citar dois desses vanguardistas no ensino acadêmico, são eles: John Peter Kolenda e Lawrence Olson. A natureza necessariamente breve deste ensaio não nos permite aprofundar nas celeumas históricas em torno do assunto. Nesse sentido, indicamos ao leitor o artigo de Altair Germano da Silva: Os antecedentes históricos da educação teológica nas Assembleias de Deus no Brasil: de 1517 a 1979; o livro de Isael de Araújo, Dicionário do Movimento Pentecostal; o livro de Silas Daniel, História da Convenção Geral das Assembleias de Deus no Brasil: os principais líderes, debates e resoluções do órgão que moldou a face do Movimento Pentecostal Brasileiro; e, o livro de Albert W. Brenda, Ouvi um recado do céu: biografia de J. P. Kolenda. Neles o leitor encontrará uma apresentação sintética e panorâmica do assunto.

Mas não foi sem muita luta e resistência que o espírito protestante logrou êxito neste quesito específico. Antes, foram décadas de calorosos e acirrados debates em torno do tema. Iniciada na década de 1940, com a chegada dos missionários estadunidenses,

a implantação de institutos teológicos vinculados às Assembleias de Deus no Brasil começou a ser concretizado [sic!] em 15 de outubro de 1958, com a fundação do IBAD - Instituto Bíblico das Assembleias de Deus na cidade de Pindamonhangaba - SP, pelo casal de missionários americanos João Kolenda Lemos e sua esposa, Ruth Doris Lemos. Em 1961, através da iniciativa do missionário N. Lawrence Olson, foi fundado no Rio de

Velasques Filho afirmam sobre o protestantismo estadunidense que "a essa altura, o protestantismo deste lado do Atlântico já é muito diferente de seu ancestral europeu. Mas o problema não termina aí. Quando esse protestantismo chegou nos Estados Unidos, muitas das disputas entre puritanos, arminianos, pietistas, unitarianos, proponentes do evangelho social, fundamentalistas e avivalistas já estavam superadas. Cada grupo havia absorvido um pouco do outro, tornando o protestantismo norte-americano uma complexidade capaz de confundir historiadores, teólogos e sociólogos" (MENDONÇA; VELASQUES FILHO, 1990, p. 108). 
Janeiro o IBP - Instituto Bíblico Pentecostal. A fundação desses institutos bíblicos de Educação Teológica formal não foi iniciativa da liderança nacional das Assembleias de Deus. Seus fundadores, verdadeiros "heróis da resistência", sofreram forte resistência da maioria dos missionários suecos e de vários obreiros nacionais (SILVA, 2013, p. 27-28, grifo do autor).

O reconhecimento desses Institutos Bíblicos ocorreu somente na década de 1970, ou seja, praticamente sessenta anos após a chegada de Vingren e Berg. Prevaleceu então o princípio protestante? Sim, em certo sentido. Em certo sentido porque a fé pentecostal detém a complexidade dos fenômenos religiosos. Logo, nada é totalmente peremptório. Sendo assim, como bem disse Huff Júnior, "o objeto é fugidio. Mas qual não é?" (2005, p. 78).

Outro elemento digno de destaque é o literalismo bíblico que vigorou (e ainda vigora) em boa parte das denominações pentecostais, inclusive a AD. Observemos, por exemplo, os textos abaixo:

Pois está escrito: Eu destruirei a sabedoria dos sábios e aniquilarei a inteligência dos inteligentes. Onde está o sábio? Onde está o doutor da lei? Onde está o raciocinador deste século? Acaso Deus não tornou louca a sabedoria do mundo? (1 Coríntios 1. 19-20, BÍBLIA TEB, grifo do autor)

Foi ele que nos tornou capazes de ser ministros de uma Aliança nova, não da letra, mas do Espírito; pois a letra mata, mas o Espírito vivifica. (2 Coríntios 3.6, BÍBLIA TEB) ${ }^{7}$

De imediato nos parece um tanto irônico que os versículos supracitados tenham sido utilizados para justificar/legitimar a mentalidade anti-intelectual ${ }^{8}$ no pentecostalismo sejam de autoria do apóstolo Paulo. Afirmamos isso porque é bem sabido que este protagonista do cristianismo primitivo foi um intelectual de sua época e um autor funda-

Todas as referências bíblicas utilizadas neste trabalho foram extraídas da TEB, isto é, da Tradução Ecumênica da Bíblia, tradução: L.J. Baraúna, et al. São Paulo: Loyola, 1994. 2480 p.

8 Tomamos aqui como referência a definição que o pesquisador do pentecostalismo Rick Nañes propôs em seu livro Pentecostal de coração e mente: um chamado ao dom divino do intelecto. Nesta obra o autor considera como anti-intelectualismo "uma predisposição contra o uso diligente e ponderado do intelecto" (2007, p. 210). Todavia, estendemos essa definição em função do nosso objeto de pesquisa. Portanto, por anti-intelectualismo, entendemos uma atitude de profunda desconfiança para com a educação superior, quando não uma aversão aberta e declarada, cujo o fito seria evitá-la, quiçá, rechaçá-la. 
mental para a teologia cristã̃ . Além disso, não se pode ignorar que "há 27 livros no Novo Testamento. 13 são cartas atribuídas a Paulo e um outro livro, os Atos dos Apóstolos, de Lucas, possui toda sua segunda metade dedicada a Paulo. Paulo toma, assim, exatamente, metade do Novo Testamento" (CROSSAN, 2009, p. 91).

Não obstante, inúmeras passagens paulinas isoladas de seu contexto foram (e ainda têm sido) utilizadas por pregadores pentecostais ao longo dos anos no intuito de encontrar um amparo bíblico que pudesse referendar seu posicionamento com relação aos binômios (por vezes pensados irreconciliáveis) como emoção-razão, mente-espírito, enfim, tudo aquilo que envolve fé versus intelecto. Pontue-se, no entanto, que essa dicotomia nunca foi exclusividade do pentecostalismo, tampouco criação sua. Sobre isso, o historiador Richard Hofstadter ${ }^{10}$ afirma "que certa tensão entre a inteligência e o coração, entre o intelecto é, em toda parte, um aspecto permanente da experiência cristã" (1967, p. 69-70).

Entrementes, ainda na década de 1990, lembro-me de ouvir não poucos comentários bastante temerosos daqueles cristãos pentecostais preocupados com o fervor espiritual do jovem que aspirava ao ministério pastoral, sobretudo quando o pretendente demonstrava o desejo de cursar um seminário teológico. Tratava-se de uma preocupação mais ou menos fundamentada numa mentalidade anti-intelectual que permeava a cosmovisão própria do pentecostalismo. Inclusive, tal mentalidade não estava restrita ao âmbito teológico somente, mas havia uma notória desconfiança, para dizer o mínimo, quanto ao estudo acadêmico nas universidades que, a seu modo de ver, tinha um imenso potencial "desviante".

Essa mentalidade anti-intelectual foi uma característica marcante no pentecostalismo nascituro, e, em certo sentido, ainda é no pente-

9 Para um aprofundamento nessa temática, remetemos o leitor ao livro do teólogo Isidoro Mazzarolo, O apóstolo Paulo: o grego, o judeu e o cristão. Rio de Janeiro: Mazarolo Editor, 2008.

10 Richard Hofstadter foi um destacado historiador norte-americano. Graduou-se pela University of Buffalo e obteve seu doutorado pela Columbia University. Exerceu a docência na University of Maryland por quatro anos, após esse período foi docente no Departamento de História da Columbia University, na qual aposentou-se. Neste texto nos valemos de sua obra intitulada: Antiintelectualismo nos Estados Unidos. Rio de Janeiro: Paz e Terra, 1967. 
costalismo brasileiro. Sobre tal tendência, Rick Nañes ${ }^{11}$ reitera o que "John R. W. Stott, notável líder e escritor, declarou em meados da década de 1970 que 'um dos traços mais sérios, pelo menos de alguns cristãos pentecostais', é o seu declarado anti-intelectualismo" (NAÑES, 2007, p. 95).

Citamos Tillich um pouco acima fazendo referência ao "orgulho religioso, arrogância eclesiástica e auto-suficiência" contra os quais o princípio protestante incide e correlacionamos o ethos assembleiano e a sua forma de governo episcopal altamente hierárquica e enrijecida a partir da assertiva de Alencar.

De fato, há no pentecostalismo da AD certo orgulho religioso que advém da experiência extática. Orgulho este, no sentido de um "poder" que faz do pentecostal um crente privilegiado e, por isso mesmo, diferenciado, talvez mais fervoroso em seu entender. A arrogância eclesiástica está diretamente ligada ao status da liderança, sobretudo do pastor presidente, conforme já explicitado anteriormente. Por seu turno, a auto-suficiência parece decorrer da noção de dependência absoluta da ação do Espírito Santo na vida do crente. Em nosso caso específico, podemos exemplificar esse sentido de auto suficiência por ocasião de uma celeuma em torno da

necessidade do ensino teológico formal e da criação de institutos bíblicos foi novamente levantado pelo pastor John Peter Kolenda. Leonard Pettersen citou na ocasião Efésios 4.11-16, e resistindo a ideia do ensino teológico formal, aconselhou a não se afastar dos princípios bíblicos na preparação dos obreiros. John Peter Kolenda, na sequência, discordou da interpretação que Pettersen dera ao texto de Efésios citado, e reafirmou a necessidade de se fundar institutos bíblicos no Brasil. Do lado de Pettersen ficou o pastor Eugênio Pires que afirmou termos uma escola, a de Jesus, que não deveria ser orientada por determinada pessoa (SILVA, 2013, p. 27-28).

Somado ao sentido de auto-suficiência baseada na dependência da ação do Espírito Santo, está o temor "“do perigo da muita sabedoria', referindo-se ao intelectualismo, à possibilidade do muito estudo esfriar

11 Rick M. Nanes é mestre em Teologia Prática pelo Luther Rice Seminary, na Geórgia, e doutor pelo Trinity Evangelical Seminary, em Indiana. É pastor ordenado pela Assemblies of God (USA). 
o obreiro" (DANIEL, 2004, p 194). Esta é uma preocupação fulcral que perpassa a vivência dos assembleianos, dada a sua teologia arminiana, particularmente a sua soteriologia e escatologia.

Tal situação revela algo que está no cerne de sua teologia, qual seja, a perspectiva da parousia iminente. A ênfase escatológica pré-milenista e dispensacionalista é uma marca do pentecostalismo como um todo e particularmente na AD. Tal preocupação teve, inclusive, desdobramentos missiológicos bastante pragmáticos:

esses discursos escatológicos foram veiculados constantemente como meio de mobilizar, converter e salvar o maior número possível de pessoas antes do arrebatamento e para conclamar seus fiéis para seguirem a vida cristã, obedecerem às normas da instituição e à sua hierarquia e se afastarem de tudo que negasse o sagrado. Os fiéis que não abandonassem o pecado e o mal continuavam a serem infiéis e seriam deixados por Jesus no arrebatamento e fariam parte da igreja apóstata e estariam sujeitos à ira de Deus (CGADB, 2014). A Igreja, diante dessa urgência, desse momento decisivo, deveria assumir sua responsabilidade e, numa corrida contra o relógio, mobilizar-se por meio de uma ação planejada para levar a salvação a todos (MARIN, 2014, p. 445).

Logo, não é de se surpreender a preocupação dos líderes escandinavos e nacionais quanto ao perigo da educação superior esfriar o obreiro ou quem quer que seja, podendo levá-lo, em última instância, à perda da salvação. Vista por este prisma a atitude anti-intelectual outrora predominante poderia até mesmo ter alguma "legitimidade".

Nesse sentido, lembremo-nos da escolástica luterana que acabou por dar ensejo ao surgimento do pietismo. Assim, o pietismo foi, também, uma reação ao intelectualismo protestante, pois ainda no período de desenvolvimento da Reforma Luterana foi dada uma ênfase exacerbada às elucubrações teológicas e especulações filosóficas que, de certa forma, geraram um luteranismo escolástico, ou como ficou mais conhecido, a "alta ortodoxia luterana" (WALKER, 1981, p. 123), da qual se pode citar como seu marco histórico inicial a promulgação, em 1577, da Fórmula de Concórdia, praticamente definindo esse luteranismo escolástico que embora 
baseado nas Escrituras, assumiu a forma de uma interpretação dogmática, fixa, rígida, exata e exigia conformidade intelectual. Era enfatizada a pura doutrina e os sacramentos como sendo os elementos suficientes da vida cristã. A relação vital entre o crente e Deus que Lutero ensinara fora substituída em grande parte por uma fé que consistia na aceitação de um todo dogmático. O papel do leigo era inteiramente passivo: aceitar os dogmas que lhes eram assegurados serem puros, ouvir sua exposição do púlpito, participar dos sacramentos e das ordenanças da Igreja - isso tudo era súmula prática da vida cristã. Existiam evidências de uma piedade mais profunda, da qual são ampla prova os hinos da época e, sem dúvida, muitos exemplos individuais de profunda vida religiosa se encontrariam, mas a tendência geral era externa e dogmática. Era a tendência por vezes denominada, ainda que só em parte com justiça, "ortodoxia morta" (WALKER, 1981, p. 190).

Com isso queremos destacar que a recusa do ensino teológico formal não é por si só condenável, pois a teologia mal aplicada pode, de fato, ressecar a fé. Por outro lado, o ensino teológico pode ser usado pela própria liderança para legitimar o seu autoritarismo. Bem, isso não se pode afirmar que ocorre na $\mathrm{AD}$, em função desse fenômeno ser recentíssimo. Qualquer afirmação nesse sentido seria mera especulação de teor temerário. Mas o que se pode depreender do acima exposto, é que parece que o princípio protestante manifestado através dos missionários estadunidenses tem rompido essa barreira anti-intelectual na AD brasileira, cujo paradigma, pensamos, é a FAECAD.

Esse contexto nos revela que, para além de uma atitude puramente anti-intelectual por si mesma, havia uma preocupação fulcral fundamentada na possibilidade da perda da salvação do crente. Ora, sob este prisma, não seria legítimo, ao menos, associar tal preocupação com o que Tillich denominou ultimate concern?

\section{Ultimate Concern: uma experiência estática?}

Antes de esclarecermos o conceito de ultimate concern, parece-nos importante dirimir uma possível suspeição quanto a nossa leitura das ênfases teológicas do pentecostalismo da AD. Talvez alguém possa indagar que a ênfase teológica do pentecostalismo recai em sua pneumatologia, dada a valorização dos carismas como práxis religiosa. Com efeito, há até mesmo abordagens acadêmicas que dão tal ensejo, como o exemplo que segue abaixo: 
A expressão religiosa pentecostal é caracterizada prioritariamente como emocional, com certo desprezo pela racionalidade da fé. Prova disso é a histórica aversão que a liderança deste movimento adotou em relação ao estudo teológico. A instalação de escolas formais de educação teológica somente foi discutida após 35 anos de instalação da igreja no Brasil, mesmo assim, o primeiro instituto bíblico foi oficialmente reconhecido 61 anos depois da fundação da igreja. Em todo o período entre a discussão inicial e o reconhecimento (e mesmo após este) houve calorosos debates sobre a necessidade e viabilidade do estudo formal, preferindo-se a loquacidade espontânea do Espírito. O medo da teologia está relacionado ao perigo da perda da experiência fundante, esta que livrou o converso de temores e culpas, portanto, impõe mecanismos de defesa contra sua reestruturação racional. A espontaneidade emocional reforça no pentecostalismo sua atitude anti-intelectual, pois a racionalidade pode aniquilar a beleza presente na manifestação das emoções (POMMERENING, 2013, p. 173, grifo nosso).

Sim, é bem verdade que a emoção é parte fundamental em qualquer tipo de religiosidade, tanto mais no pentecostalismo. As manifestações carismáticas são sempre carregadas de emoção, isso é patente. Mas ao contrário do que possa parecer, a experiência fundante é a conversão. A fortiori, só se pode denominar de pentecostal um cristão, no sentido estrito. Há, portanto, cristãos protestantes, cristãos ortodoxos, cristãos católico-romanos, e, cristãos pentecostais, dentre tantos outros. Assim, a conversão ganha relevo na medida em que a maioria absoluta dos pentecostais não é adepta do batismo de infantes. Ora, por esse prisma, o "aceitar a Jesus" ou "ter um encontro com Jesus" é a experiência fundante no pentecostalismo, lembrando que a glossolalia é sempre posterior à conversão, inclusive na literatura neotestamentária. No pentecostalismo o rito de passagem, isto é, o batismo, também é posterior à conversão.

Nesse sentido é que se pode afirmar que a experiência fundante também no pentecostalismo é a conversão. Por outro lado, sabe-se que uma evidência externa do batismo no Espírito Santo é conditio sine qua non para se tornar de fato um pentecostal "pleno". Embora o autor supracitado reconheça em parte que a conversão precede e que é a partir dela que se pode desencadear a experiência pentecostal, o acento, contudo, ainda recai sobre a emoção e o êxtase, conforme podemos perceber: 
Embora no escopo das doutrinas pentecostais não se conheça o termo êxtase, este cabe perfeitamente para definir o momento de conversão (condição preliminar para as demais manifestações), o batismo com o Espírito Santo ou a manifestação dos dons espirituais, bem como em outras manifestações físicas, mentais e emocionais decorrentes do enlevo que o indivíduo sente no momento da "manifestação do Espírito", do "revestimento de poder", da "unção", ou da "visitação", utilizando os predicados próprios do pentecostalismo (POMMERENING, 2013, p. 174, grifos do autor).

Ademais, no exato momento da conversão, emoção e razão estão necessariamente imbricadas, ou seja, são inextricáveis. Na conversão, há que se ter, por um lado, o assentimento racional, isto é, a intelectiva compreensão da mensagem salvífica e a consequente adesão pessoal; mas por outro lado, não se pode prescindir do ser tocado ou tomado pelo sagrado ou incondicional também nessa experiência religiosa fundante.

Nesse ponto, Tillich contribui significativamente, pois para o nosso autor

razão é uma condição necessária para a fé, e fé é o ato em que a razão irrompe extaticamente para além de si. Essa é a unidade e a diferença entre as duas. (...) Êxtase é razão realizada, e não razão quebrada. (...) Razão é a pressuposição da fé, e fé preenche a razão. Entre a natureza verdadeira da fé e a natureza verdadeira da razão não há contradição (1996, p. 51).

Isto posto, é necessário sublinhar que muito embora o êxtase e a manifestação dos carismas sejam importantes, diferem da salvação qualitativamente e, por isso mesmo, prioritariamente. No inicio de sua obra A dinâmica da fé, Tillich faz uma distinção entre preocupação preliminar (que pode até ser urgente) e preocupação suprema. Em nosso entender, o carismatismo estaria mais voltada para uma preocupação preliminar, conquanto também seja urgente (para os pentecostais, obviamente), e a salvação estaria mais voltada para uma preocupação última.

Segundo Tillich, "a religião revela a profundidade da vida espiritual, encoberta, em geral, pela poeira de nossa vida cotidiana e pelo barulho de nosso trabalho secular. Dá-nos a experiência do sagrado, intangível, tremendamente inspirador, significado total e fonte de coragem suprema" (2009, p. 45). Assim, para o nosso autor, "fé é estar possuído 
por aquilo que nos toca incondicionalmente" (TILLICH, 1996, p. 5). Em suma: "fé é preocupação última ou suprema"12 (GROSS, 2013, p. 8). Ora, não é nenhuma novidade que "a expectativa escatológica de um reino de Deus futuro (pré-milenarismo), [foi] característica do início do pentecostalismo" (SIEPIERSKI, 1997, p. 52). Assim, a centralidade da perspectiva da concretização da salvação sempre esteve no cerne do ultimate concern pentecostal.

Não queremos hipertrofiar a palavra salvação em detrimento de todo arcabouço teológico-doutrinário assembleiano, mas parece-nos notório que há pelo menos três décadas atrás, o eixo central dessa teologia pentecostal ainda era a escatologia. Tal perspectiva apontava necessariamente para o celeste porvir, bem como a demonização deste mundo e o necessário apartamento deste pelo fiel pentecostal.

Trata-se de uma questão de não somenos importância, pois sua perspectiva escatológica pré-milenista e dispensacionalista, associada à soteriologia de matriz arminiana, enseja a possibilidade do decaimento da graça ou, como é mais comumente conhecida, a perda da salvação. Daí insistirmos na relevância e centralidade da salvação. Em última instância o pentecostal vive sempre numa situação limite, pois em sua vivência religiosa está constantemente subjacente o adágio mateano ${ }^{13}$ que indaga de que adianta ganhar o mundo inteiro e perder a sua alma.

Portanto, trata-se não de um conteúdo teológico simplesmente, mas de um aspecto qualitativo da experiência religiosa pentecostal. Há que se destacar que devido à rígida hierarquia assembleiana, associada ao desinteresse inicial pelo estudo teológico, essa dimensão de profundidade da experiência religiosa pentecostal tornou-se heterônoma, segundo a concepção teológica tillichiana. Esse termo refere-se à questão do nomos, ou lei da vida (TILLICH, 1992, p. 84).

Entendendo como heterônoma a cultura que "submete as formas e as leis do pensamento e da ação ao critério da autoridade da religião eclesiástica" (TILLICH, 1992, p. 85), é plausível afirmar que o ethos

12 Cumpre alertar o leitor que o conceito de fé em Tillich não é algo de fácil apreensão. Não cabe aqui dissertarmos sobre o assunto. Para uma melhor compreensão do assunto, recomendamos ao leitor o texto Eduardo Gross: O conceito de Fé em Paul Tillich. Pontuamos também que utilizaremos o conceito num sentido um pouco mais elástico ou lato sensu neste ensaio.

13 A referência feita aqui consta na perícope de Mt 16.24-28. 
pentecostal fora heteronomizado a partir de uma hipertrofia de sua concepção escatológica e soteriológica. Embora reconheçamos que a fé como ultimate concern somente pode se realizar através de formas culturais condicionadas, é preciso admitir o risco da reificação ou fossilização da preocupação suprema, em conteúdos ou formas culturais, cujo resultado é a idolatria, a heteronomia ou até mesmo tornar-se demoníaco, que seria a perversão total da religião.

Nesse contexto a educação superior, evidentemente, não poderia ser valorizada, ao contrário, foi enxergada como uma injustificada perda de tempo e um perigo real para a fé do fiel da AD. Sobretudo por possibilitar um arrefecimento espiritual que, no limite, poderia tirar-lhe a salvação. Assim, a educação superior vinha passando longe do ethos assembleiano. A preparação para a parousia e a manutenção da salvação, estas sim estavam no cerne da vivência religiosa pentecostal. Mas, sobretudo, a salvação

pela forte ênfase que esta põe na sociedade futura a ser instaurada com a vinda de Cristo, opera-se um corte ente o crente e sua situação concreta na sociedade. Segundo, esta mesma percepção deixa em plano secundário e a bem dizer esquecido o «hic et nunc» da ação pentecostal (ROLIM, 1985, p. 224-225).

\section{Portanto,}

diante dessa tradicional demonização do mundo e da cultura, a questão chave do discurso e prática pentecostal é de que maneira as pessoas podem escapar da condenação e serem salvas desse mundo mau. A partir da escatologia pentecostal, a história acaba sendo valorizada apenas como um elemento para a vida terrena. As comunidades pentecostais são concebidas principalmente como instituições da salvação de indivíduos, não como comunidade que antecipa o Reino de Deus (ALBANO, 2014, p. 410-411).

Para além dessa pretensa apatia com relação às questões de engajamento político-social, percebemos que a salvação da alma tem sido parte do ultimate concern assembleiano. Mas a grande questão é: o Ultimate Concern é uma experiência estática? 
Baseamos nosso questionamento na assertiva tillichiana de que "a fé é o estado de estar possuído por algo que nos toca incondicionalmente. Está certo que o conteúdo especifico da fé é de máxima importância para o crente, mas este conteúdo é irrelevante para a definição de fé” (1996, p. 7, grifo nosso). Conforme já explicitamos anteriormente, não buscamos aqui definir o conceito de fé, mas para nossa reflexão a vivência religiosa assembleiana, isto é, a dimensão de profundidade do espírito humano, é deveras significativa. Significativa em primeiro lugar porque importa saber se, de fato, essa vivência religiosa é uma experiência estática, ou seja, não muda, não varia; e em segundo lugar, se ela pode variar, o que faria com que tal experiência visceralmente essencial mudasse.

É o próprio pensamento de Tillich que lança luz sobre tais questionamentos. Para Tillich,

a religião, considerada como preocupação suprema, é a substância que dá sentido à cultura, e a cultura, por sua vez, é a totalidade das formas que expressam as preocupações básicas da religião. Em resumo: religião é a substância da cultura e a cultura é a forma da religião. Com isso evita-se o dualismo entre religião e cultura. Cada ato religioso, não apenas da religião organizada, mas também dos mais íntimos movimentos da alma, é formado culturalmente (2009, p. 83).

Sob esse prisma e considerando essa relação dialética fica mais fácil inferir as respostas que nos interessam. Citando Gedeon Alencar, Fernando Albano oferece pistas para a compreensão do que significou a influência mútua entre religião e cultura na (con)formação da ênfase escatológica enquanto elemento de sua preocupação última. Isso tendo em mente que

"o pentecostalismo moderno surge no final do século XIX e se consolida nas primeiras décadas do século XX. Período áureo entre a I e II Guerra Mundial com o perigo nuclear rondando como espectro" (ALENCAR, 2005, p. 64). Então, há uma constelação de elementos de crise, medo e angústias semelhantes à sociedade judaica em sua subjugação às potências estrangeiras. Também em comum com aqueles, os sonhos e ideais de uma irrupção da ação libertadora de Deus, de cunho inteiramente sobrenatural (ALBANO, 2014, p. 410). 
Contextualizando sua gênese, então, não é de se espantar que a ênfase escatológica milenarista permeasse o ideário pentecostal. Tal contexto cultural forneceu elementos para a (con)formação da preocupação suprema pentecostal. Logo, se assim foi, o ultimate concern pode não ser uma experiência estática.

Segundo o cientista da religião Arnaldo Érico Huff júnior,

a espiritualidade age como "unidade dinâmica do conteúdo de uma fé e da maneira pela qual esta é vivida por homens historicamente determinados", compreendendo "a vivência de um relacionamento inspirado pela religião" e guardando, assim, profundas implicações e comprometimentos sociais. É algo semelhante à fé como uma "preocupação última" ou como aquilo "que nos preocupa incondicionalmente", como sugere Tillich, e confere, portanto, um conteúdo religioso às práticas sociais de indivíduos e instituições. Enquanto fenômenos sócioculturais, portanto, as estruturas espirituais das tradições religiosas são regularmente expostas a processos históricos em conjunturas sociais determinadas (2005, p. 79).

Dinâmica da fé é o título de uma das obras de Tillich que reflete bem a natureza dos fenômenos religiosos, dentre os quais podemos incluir aqui o pentecostalismo da AD. No caso do objeto de estudo específico deste ensaio, o que Huff Júnior denominou processos históricos, talvez seja o princípio protestante atuando na história. Quem sabe? Mas o fato é que a qualidade intrínseca do ultimate concern pentecostal pode dialogar com a cultura e a cultura normalmente expressa tais preocupação.

É assim que pensamos ser possível a primavera educacional pentecostal na $\mathrm{AD}$ que apontamos estar ocorrendo no pentecostalismo da AD. Contudo, este devir enseja outros questionamentos. Por exemplo, se

a expectativa escatológica de um reino de Deus futuro (pré-milenarismo), característica do início do pentecostalismo, é modificada para uma escatologia realizada. O reino de Deus já está presente aqui e agora, embora ainda não de forma definitiva, para usufruto dos escolhidos. O batismo no Espírito Santo é o revestimento de poder para vencer os entraves para tal usufruto (SIEPIERSKI, 1997, p. 52),

é perceptível que houve uma mudança significativa no eixo teológico pentecostal. Quais implicações práticas isso geraria (ou tem gerado)? 
Essa mudança descaracterizaria (ao menos no âmbito teológico) parcialmente o pentecostalismo?

Responder a tais questionamentos demanda, necessariamente, observar o objeto por uma tessitura temporal maior. O que se pode enxergar, por ora, são sinais, indícios e mudanças pontuais. Pontuais, porém, concomitantemente promissoras e significativas como, por exemplo, o arrefecimento do anti-intelectualismo e a primavera educacional hodierna na $\mathrm{AD}$, cujo paradigma, afirmamos, é a FAECAD. Portanto, nossa proposta de estudo requer um maior tempo de observação e um aprofundamento na análise e, nesse sentido, pensamos que a teologia de Tillich ainda tem muito a contribuir nesse fito.

Por fim, com base no que expomos da teologia tillichiana,

é possível afirmar que a imposição de qualquer cultura religiosa sobre dissidentes ou participantes de outras culturas nunca terá caráter final não obstante pretender alcançar os corações humanos, mas sempre será provisória e condicionada porque apenas aproveita em seu benefício o caráter supremo da religião (TILLICH, 1992, p. 85).

Portanto, pensamos que sim, há vestígios de um princípio protestante no pentecostalismo assembleiano, mormente se pensarmos na primavera educacional que ocorre na $\mathrm{AD}$. Contudo, há que se ressaltar que a educação teológica formal só se justifica, do ponto de vista do princípio protestante, se ela for crítica. Ademais, cremos que será salutar para essa denominação que esse princípio crítico que julga e condena a absolutização de qualquer elemento religioso, seja ele liderança, teologia ou práxis religiosa, seja não apenas vestígio, mas um princípio norteador rumo a uma cultura teônoma.

\section{Considerações finais}

Por fim, talvez seja interessante explicitar que deste ensaio não resulta qualquer tipo de panacéia ou resposta peremptória às questões postas sob a luz da teologia tillichiana. O que de fato quisemos com este ensaio foi apresentar uma via interpretativa na qual o objeto não fosse reduzido a uma função social apenas.

Para tanto, o arcabouço teólogico tillichiano nos forneceu dois elementos bastante profícuos no intuito de compreender o fenômeno, 
quais sejam, o princípio protestante e o ultimate concern. A partir desses dois elementos cotejamos duas questões principais que o próprio objeto ensejou. A primeira abordagem tem relação íntima com o título que demos ao ensaio, pois procuramos verificar se de fato haveria indícios para se poder falar de um principio protestante no pentecostalismo da AD. Pensamos que sim, sobretudo em relação à educação superior na $\mathrm{AD}$, que é o nosso objeto propriamente dito. A segunda abordagem decorre da primeira, pois, conforme discorremos, através da atuação do princípio protestante a educação superior tem conseguido romper o anti-intelectualismo na $\mathrm{AD}$. Mas essa ferrenha resistência à educação superior revelou ser motivada por preocupações ontológicas. Aliás, sagradas, ou melhor, na verdade, preocupação suprema. E essa última, ressalte-se, não está fossilizada.

Portanto, procuramos analisar, iluminados por Tillich, essas questões fundamentais que talvez em outras abordagens, com outros referenciais teóricos seriam relacionadas (para não dizer reduzidas) a meras dicotomias como anti-intelectualismo/pobreza, educação superior/ascensão social, etc. Por isso assinalamos inicialmente que nossa proposta se constitui uma alternativa a tais abordagens e advertimos o leitor que a proposta deste texto talvez seja mais pretensiosa no título do que no conteúdo propriamente dito, mas isso não quer dizer que a proposta esteja invalidada ou a sua contribuição irrelevante. Antes, pensamos que a partir dessa leitura talvez se possa prosseguir na compreensão do fenômeno num horizonte hermenêutico, como o de Tillich, que dê conta com a devida propriedade da magnitude heurística que os fenômenos religiosos ensejam.

\section{Referências}

ALBANO, Fernando. Escatologia pentecostal: aspectos íntimos e implicações públicas. Caminhos, Goiânia, v. 12, n. 2, p. 407-415, jul./dez. 2014. Disponível em: <http://seer.ucg.br/index.php/caminhos/article/viewFile/3549/2059>. Acesso em: 25 dez. 2014.

ALENCAR, Gedeon Freire de. Assembleias Brasileiras de Deus: teorização, história e tipologia - 1911 - 2011. 2012. 285 p. Tese (Doutorado em Ciências da Religião) - FCS, Pontifícia Universidade de São Paulo, São Paulo, 2012.

BÍBLIA. Português. BÍBLIA - Tradução Ecumênica. Tradução: L.J. Baraúna, et al. São Paulo: Loyola, 1994. 
CROSSAN, John Dominic. As duas vozes mais antigas da tradição de Jesus. In: CHEVITARESE, André Leonardo; CORNELI, Gabriele. (Orgs.). A descoberta do Jesus histórico. $1^{\text {a }}$ Ed. São Paulo: Paulinas, 2009. p. 85-104.

DANIEL, Silas. (Org.) História da Convenção Geral das Assembleias de Deus no Brasil. Os principais líderes, debates e resoluções do órgão que moldou a face do Movimento Pentecostal Brasileiro, $1^{\mathrm{a}}$ ed., Rio de Janeiro: CPAD, 2004.

GROSS, Eduardo. O conceito de Fé em Paul Tillich. Correlatio, São Bernardo do Campo, v. 12, n. 23, p. 7-26, jun. 2013. Disponível em: <https://www. metodista.br/revistas/revistas-ims/index.php/COR/article/view/4196/3672>. Acesso em: 10 jul. 2014.

HOFSTADTER, Richard. Antiintelectualismo nos Estados Unidos. Rio de Janeiro: Paz e Terra, 1967.

HUFF JÚNIOR, Arnaldo Érico. Espiritualidade, processos e práticas sociais um estudo sobre luteranismo confessional no Brasil. Correlatio, São Bernardo do Campo, v. 4, n. 7, p. 77-103, dez. 2005. Disponível em: <https://www. metodista.br/revistas/revistas-ims/index.php/COR/article/view/1754/1745>. Acesso em: 15 dez. 2014.

MARIN, Jérri Roberto. A Assembleia de Deus nos anos de 1990: a "Década da Colheita". Horizonte, Belo Horizonte, v. 12, n. 34, p. 436-464, abr./jun. 2014. Disponível em: <http://periodicos.pucminas.br/index.php/horizonte/ article/view/P.2175-5841.2014v12n34p436/6687>. Acesso em: 05 jul. 2014.

MENDONÇA, Antonio Gouvêa; VELASQUES FILHO, Prócoro. Introdução ao Protestantismo no Brasil. São Paulo: Loyola. 1990.

MOURA, Luana Cristina Baracho de. Espaço e lugar sagrado: vivência e percepção pentecostal assembleiana. Revista Relegens Thréskeia, Curitiba, v. 3, n. 2, p. 130-154, jul/dez. 2014. Disponível em: <http://ojs.c3sl.ufpr.br/ ojs2/index.php/relegens/article/view/39096/23883 >. Acesso em: 19 dez. 2014.

NAÑES, Rick M. Pentecostal de coração e mente: um chamado ao dom divino do intelecto. São Paulo: Editora Vida, 2007.

POMMERENING, Claiton Ivan. Paul Tillich e a compreensão do fenômeno religiosos pentecostal. Correlatio, São Bernardo do Campo, v. 12, n. 24, p. 171-185, dez. 2013. Disponível em: <https://www.metodista.br/revistas/revistas-ims/index.php/COR/article/view/4507/4007>. Acesso em: 15 dez. 2014.

SIEPIERSKI, Paulo Donizéti. Pós-pentecostalismo e política no Brasil. Estudos Teológicos, São Leopoldo, v. 37, n. 1, p. 47-61, 1997. Disponível em: $<$ http://est.tempsite.ws/periodicos/index.php/estudos_teologicos/article/viewFile/776/711>. Acesso em: 16 jan. 2014. 
SILVA, Altair Germano da. Os antecedentes históricos da educação teológica nas Assembleias de Deus no Brasil: de 1517 a 1979. Voz Faifae, Goiânia, v. 5, n. 3, p. 1-30, 2013. Disponível em: <http://www.faifa.edu.br/revista/index. php/voxfaifae/article/view/83/94>. Acesso em: 30 out. 2013.

ROLIM, Francisco Cartaxo. Pentecostais no Brasil: uma interpretação sócio-religiosa. Petrópolis: Vozes, 1985. 260 p.

TILLICH, Paul. A era protestante. São Paulo: ASTE, 1992.

. Dinâmica da fé. 5a Edição. São Leopoldo: Editora Sinodal, 1996.

. Teologia da cultura. São Paulo: Fonte, 2009.

WALKER, Williston. História da Igreja Cristã. $3^{\text {a }}$ ed. v. 2. Rio de Janeiro: JUERP; São Paulo: ASTE, 1981. 